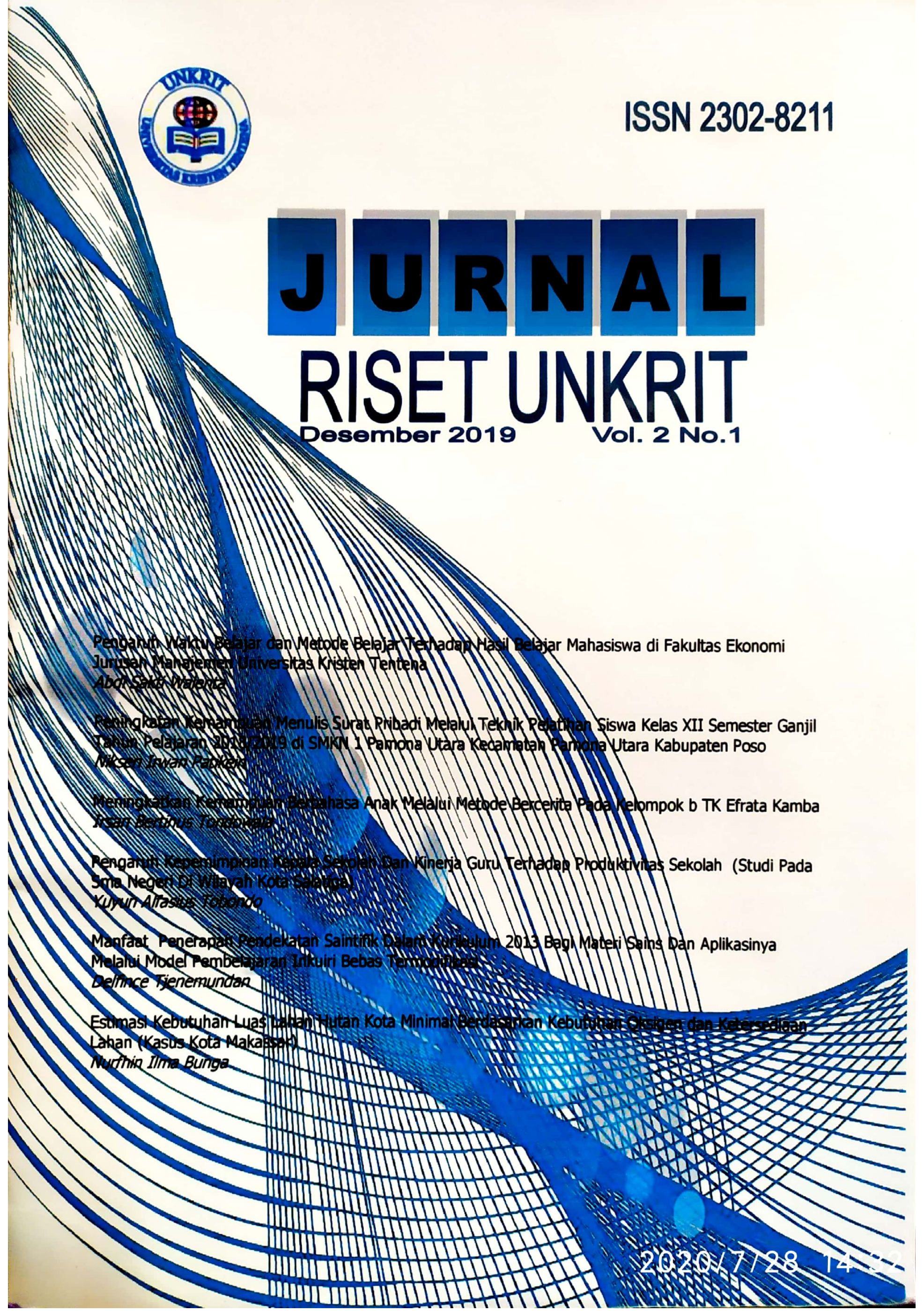




\section{DAFTAR ISI}

Kata Pengantar.

Daftar Isi

Pengaruh Waktu Belajar dan Metode Belajar Terhadap Hasil Belajar Mahasiswa di Fakultas Ekonomi Jurusan Manajemen Universitas Kristen Tentena.

Peningkatan Kemampuan Menulis Surat Pribadi Melalui Teknik Pelatihan Siswa Kelas XII Semester Ganjil Tahun Pelajaran 2018/2019 di SMKN 1 Pamona Utara Kecamatan Pamona Utara Kabupaten Poso.

Meningkatkan Kemampuan Berbahasa Anak Melalui Metode Bercerita Pada Kelompok b TK Efrata Kamba.

Pengaruh Kepemimpinan Kepala Sekolah Dan Kinerja Guru Terhadap Produktivitas Sekolah (Studi Pada Sma Negeri Di Wilayah Kota

Salatiga)

Manfaat Penerapan Pendekatan Saintifik Dalam Kurikulum 2013 Bagi Materi Sains Dan Aplikasinya Melalui Model Pembelajaran Inkuiri Bebas Termodifikasi

Estimasi Kebutuhan Luas Lahan Hutan Kota Minimal Berdasarkan Kebutuhan Oksigen dan Ketersediaan Lahan (Kasus Kota Makassar). 


\title{
Pengaruh Kepemimpinan Kepala Sekolah Dan Kinerja Guru Terhadap Produktivitas Sekolah
}

\section{(Studi Pada Sma Negeri Di Wilayah Kota Salatiga)}

\author{
Yuyun Alfasius Tobondo \\ Fakultas Keguruan dan Ilmu Pendidikan \\ Universitas Kristen Tentena \\ Email : alfa.trumpp@gmail.com
}

\begin{abstract}
Abstrak
Saat ini institusi pendidikan dihadapkan pada berbagai macam persoalan, khususnya yang berkaitan dengan pengelolaan sekolah agar dapat menciptakan sekolah yang produktif. Hal tersebut juga terjadi pada institusi SMA di Kota Salatiga. Tuntutan masyarakat terhadap kualitas pendidikan selalu meningkat setiap waktu seiring dengan rasio jumlah siswa yang bersekolah pada jenjang sekolah menengah atas di Kota Salatiga. Prestasi yang diraih tidak lepas dari peran kepemimpinan kepala sekolah yang merupakan motor penggerak di sekolah dan peran guru sebagai pendidik di lingkungan sekolah dalam mewujudkan pencapaian produktivitas sekolah yang baik.

Hipotesis yang diuji dalam penelitian ini adalah pengaruh variabel bebas (independent) kepemimpinan kepala sekolah $\left(X_{1}\right)$, dan kinerja guru $\left(X_{2}\right)$, terhadap variabel terikat (dependent) produktivitas sekolah $(Y)$. Berdasarkan hasil penelitian, maka didapat kesimpulan, yakni terdapat pengaruh positif antara kepemimpinan kepala sekolah dengan produktivitas sekolah sebesar $B_{x 1}=0,082$, antara kinerja guru dengan produktivitas sekolah sebesar $B_{x 2}=0,421$, serta antara kepemimpinan kepala sekolah dan kinerja guru dengan produktivitas sekolah sebesar $F$ $=20,164 ;$ sig $=0,000$.
\end{abstract}

Kata kunci : kepemimpinan, kinerja, kinerja guru, produktivitas, produktivitas sekolah

\section{Pendahuluan}

Pendidikan merupakan kebutuhan paling mendasar untuk pengembangan kualitas sebuah bangsa terlebih di era globalisasi dewasa ini, kualitas suatu bangsa sangat ditentukan oleh kualitas sumber daya manusia, dan selanjutnya kualitas sumber daya manusia sangat bergantung pada kualitas pendidikan, dan hal ini merupakan hubungan timbal balik antara pendidikan dan kemajuan bangsa. 
Dunia pendidikan tidak hanya dituntut dari segi kuantitas, namun juga kualitas yang menuntut terciptanya sumberdaya manusia yang cakap dan berdaya saing tinggi dan beriringan dengan mutu pelayanan dalam dunia pendidikan. Oleh karena itu, peningkatan mutu pelayanan yang kemudian bermuara pada peningkatan mutu pendidikan merupakan hal yang tidak dapat ditawar-tawar (Supriadi, 2004:104).

Pendidikan menjadi salah satu jalan keluar untuk meningkatkan sumber daya manusia, baik dari sisi IPTEK (IImu Pengetahuan dan Teknologi), maupun keterampilan formal dan non-formal yang dimiliki oleh setiap insan pendidikan. Menyadari hal tersebut, setiap kepala sekolah dihadapkan pada tantangan untuk melaksanakan pengembangan pendidikan secara terarah, berencana, dan berkesinambungan untuk meningkatkan kualitas pendidikan (Mulyasa, 2011:25)

Selain kepala sekolah, menurut Wahjosumidjo (2003:271) Para guru merupakan bagian integral dari keberadaan sumber daya manusia yang mempunyai peranan strategis dalam kehidupan suatu sekolah. Kinerja guru yang tinggi sangat diperlukan dalam sekolah dengan tujuan untuk menjaga kualitas sekolah seperti yang disyaratkan Badan Nasional Standar Pendidikan (BNSP) melalui Peraturan Pemerintah Republik Indonesia Nomor 19 Tahun 2005 tentang Standar Nasional Pendidikan.

Bahri (2011) mengatakan bahwa, kinerja guru adalah kualitas pekerjaan, kuantitas pekerjaan, kreativitas, tanggung jawab, kerjasama, dan disiplin kerja/loyalitas yang harus dimiliki oleh guru dalam melaksanakan tugas sesuai dengan tugas pokok dan fungsinya. Kinerja juga dipengaruhi beberapa faktor, yaitu : menyangkut pernyataan tentang maksud dan nilai-nilai, manajemen strategis, manajemen sumber daya manusia, pengenmbangan organisasi, konteks organisasi, desain kerja, fungsionalitas, budaya dan kerjasama (Wibowo 2007:81)

Produktivitas sekolah berkaitan dengan bagaimana menghasilkan lulusan, baik secara kuantitas maupun kualitas (Engkoswara dan Aan, 2010:40). Dapat dikatakan sumber daya manusia yang dihasilkan dari output produktivitas sekolah dan dapat bersaing secara jumlah ataupun mutu lulusan yang pemerintah.

Kejelasan ukuran pencapaian produktivitas pendidikan di Indonesia sangat ditentukan oleh pencapaian sekolah dalam mengimplementasikan program dan proses layanan menuju pada standar produktivitas pendidikan yang diharapkan dalam seluruh standar isi dan standar kompetensi lulusan, dengan didukung dengan terpenuhinya standar pendidik dan tenaga kependidikan, 

sarana dan parasarana, pengelolaan, penilaian, pembiayaan dan
lain-lain.

Secara kasat mata, kita dapat mengidentifikasi suatu layanan pendidikan itu produktif apabila siswa dapat mengatakan pelayanan pendidikan ini produktif dengan karakteristik yang muncul, yaitu guru/kepala sekolah cepat tanggap terhadap kebutuhan/keluhan, penuh simpatik dan dapat memberikan solusi (Engkoswara dan Aan, 2010:41). Artinya guru dan kepala sekolah sekolah memiliki perhatian yang terfokus kepada para siswanya, serta sabar dan dapat menjadi orang tua kedua untuk para siswa
di sekolah.

Beberapa riset mengenai kepemimpinan kepala sekolah ditunjukkan dengan penelitian yang dilakukan oleh Prasanti (2014). Penelitian ini melihat pengaruh kepemimpinan kepala sekolah terhadap produktivitas sekolah, dan hasil penelitianya menunjukkan bahwa terdapat pengaruh antara kepemimpinan kepala sekolah dengan produktivitas sekolah, namun kepemimpinan kepala sekolah saja tidak cukup, guru sebagai ujung tombak dalam meningkatkan produktivitas sekolah, untuk itulah kinerja guru menjadi penting. Demikian juga penelitian yang dilakukan oleh Rosidi (2011). Dengan pertimbangan tersebut penelitian ini akan melihat pengaruh antara kepemimpinan kepala sekolah, kinerja guru terhadap produktivitas sekolah.

Saat ini institusi pendidikan dihadapkan pada berbagai macam persoalan, khususnya yang berkaitan dengan pengelolaan sekolah agar dapat menciptakan sekolah yang produktif. Hal tersebut juga terjadi pada institusi SMA di Kota Salatiga. Tuntutan masyarakat terhadap kualitas pendidikan selalu meningkat setiap waktu seiring dengan rasio jumlah penduduk yang bersekolah pada jenjang sekolah menengah atas di Kota Salatiga.

Tabel 1.Angka Partisipasi Sekolah (APK) dan Angka Partisipasi Murni (APM)

\begin{tabular}{ccc}
\hline Tahun & APK & APM \\
\hline $2012 / 2013$ & 111,32 & 80.36 \\
$2013 / 2014$ & 109,81 & 86,40 \\
$2014 / 2015$ & 102,06 & 85,65 \\
\hline
\end{tabular}

Data di atas menunjukkan Angka Partisipasi Kasar (APK) SMA/MA/SMK Sederajat Kota Salatiga pada tahun 2012/2013 sebesar 111,32\%, pada tahun 2013/2014 sebesar 109,81\%, dan pada tahun 2014/2015 sebesar 102,06. Dan Angka Partisipasi Murni (APM) SMA/MA/SMK Sederajat Kota Salatiga pada tahun $2012 / 2013$ sebesar $80.36 \%$, pada tahun 2013/2014 sebesar $86,40 \%$, dan pada tahun $2014 / 2015$ sebesar 85,65 .

Keseluruhan prestasi yang diraih oleh sekolah-sekolah tersebut tentu tidak datang begitu saja. Prestasi yang diraih tidak lepas dari peran kepemimpinan kepala sekolah yang merupakan motor penggerak di sekolah dan peran guru sebagai pendidik di 
lingkungan sekolah dalam mewujudkan pencapaian produktivitas sekolah yang baik.

Berdasarkan pada latar belakang di atas, maka penulis merumuskan permasalahan sebagai berikut:

- Apakah terdapat pengaruh kepemimpinan sekolah terhadap produktivitas sekolah SMA Negeri di wilayah Kota Salatiga?

- Apakah terdapat pengaruh kinerja guru terhadap produktivitas sekolah SMA Negeri di wilayah Kota Salatiga?

- Apakah terdapat pengaruh kepemimpinan kepala sekolah dan kinerja guru secara bersama-sama terhadap produktivitas sekolah SMA Negeri di wilayah Kota Salatiga?

Sedangkan tujuan yang hendak dicapai melalui penelitian ini adalah sebagai berikut:

- Menganalisis adanya pengaruh kepemimpinan kepala sekolah terhadap produktivitas sekolah SMA Negeri di wilayah Kota Salatiga.

- Menganalisis adanya pengaruh kinerja guru terhadap produktivitas sekolah SMA Negeri di wilayah Kota Salatiga.

- Menganalisis adanya pengaruh kepemimpinan kepala sekolah dan kinerja guru secara bersama-sama terhadap produktivitas sekolah SMA Negeri di wilayah Kota Salatiga.

\section{Jenis Penelitian}

\section{Metode Penelitian}

Penelitian yang dilakukan adalah penelitian kuantitatif yang berlandaskan pada filsafat positivisme, digunakan untuk meneliti pada populasi atau sampel tertentu, teknik pengambilan sampel pada umumnya dilakukan secara random, pengumpulan data menggunakan instrumen penelitian, analisa data bersifat kuantitatif/statisik dengan tujuan untuk menguji hipotesis yang telah ditetapkan (Sugiyono, 2008:14). Metode yang digunakan dalam penelitian ini adalah metode deskriptif dengan menggunakan alat ukur analisis regresi berganda. Regresi berganda melihat adanya hubungan kausalitas dan pengaruh antara variabel bebas terhadap variabel terikat. Adapun variabel terikat dari penelitian ini adalah produktivitas sekolah $(Y)$ dan variabel bebas adalah kepemimpinan kepala sekolah $\left(X_{1}\right)$ dan kinerja guru $\left(X_{2}\right)$. Penelitian mengambil lokasi Sekolah Menengah Atas Negeri di Salatiga. Adapun SMA tersebut adalah SMAN 1 Salatiga, SMAN 2 Salatiga, dan SMAN 3 Salatiga. Pemilihan ketiga SMA tersebut dianggap sangat representatif dari SMA seluruh Salatiga.

Populasi penelitian ini dilakukan di Sekolah Menengah Negeri yang berada di wilayah Kota Salatiga. Sampel yang kami ambil adalah guru SMA negeri di Salatiga yang berusia diatas 35 tahun dan berjumlah 100 orang, dengan asumsi bahwa mereka sudah mempunyai pengalaman dalam mengajar, sehingga aras
penilaiannya lebih objektif. 
Metode yang dipergunakan dalam penelitian ini adalah metode survei dengan pendekatan regresi, adapun alat yang digunakan adalah kuesioner dengan menggunakan 5 (lima) skala likert dengan pembobotan sebagai berikut:

Tabel 2.1 Skor Pembobotan Kuesioner

\begin{tabular}{lll}
\hline No & Pilihan jawaban & Skor \\
\hline 1 & Tidak Sesuai Kenyataan (TSK) & 5 \\
2 & Sebagian Sesuai Kenyataan (SSK) & 4 \\
3 & Cukup Memenuhi Kenyataan (CMK) & 3 \\
4 & Sebagian Besar Sesuai Kenyataan (SBSK) & 2 \\
5 & Sesuai Kenyataan (SK) & 1 \\
\hline & Penelitian ini untuk membuktikan korelasi antara tiga
\end{tabular}

variabel utama, yaitu variabel bebasnya adalah kepemimpinan kepala sekolah dan kinerja guru, sedangkan variabel terikatnya adalah produktivitas sekolah, sebagaimana yang dijelaskan dalam gambar alur penelitian, sebagai berikut:

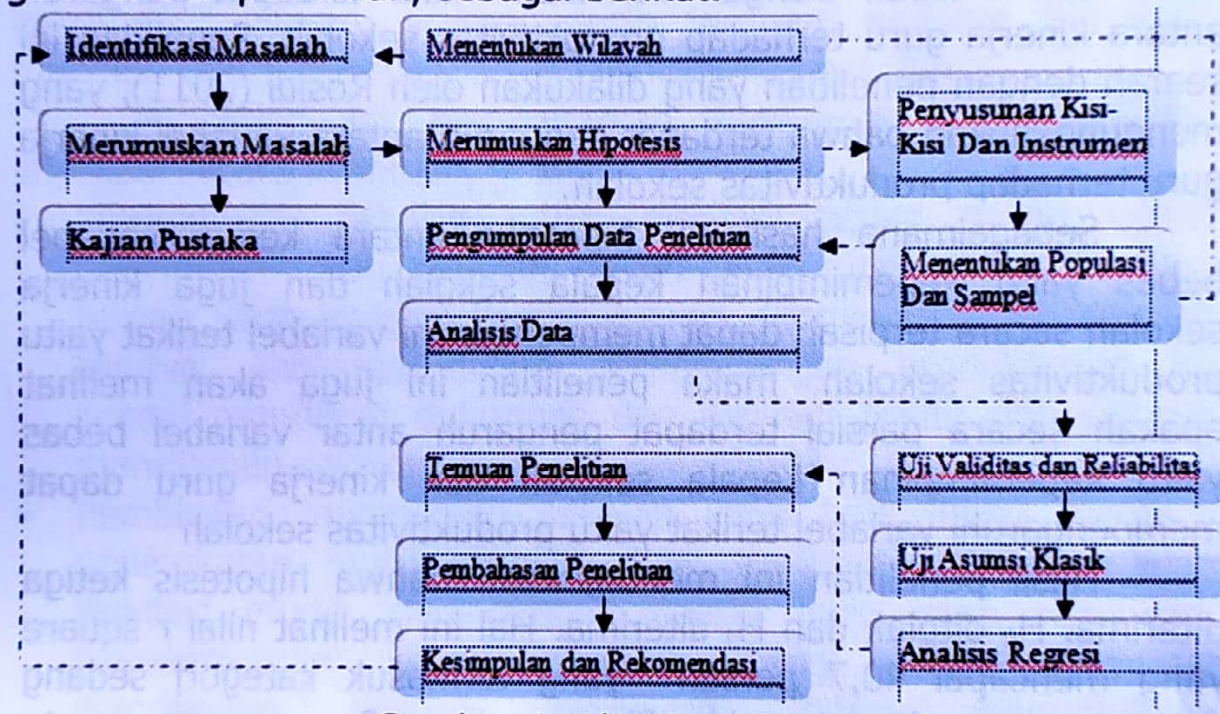

Gambar 1. Alur Penelitian

Variabel dalam penelitian ini terdiri dari 3 (tiga) variabel, yaitu 2 (dua) variabel bebas (independent variable) dan 1 (satu) variabel terikat (dependent variable). Variabel bebas adalah kepemimpinan kepala sekolah, kinerja guru, sedangkan variabel terikat adalah produktivitas sekolah.Berikut ini akan dijabarkan definisi operasional variabel penelitian.

Pengembangan instrumen penelitian ditempuh dengan beberapa cara, yakni: a) mendefinisikan operasional variabel penelitian. b) menyusun indikator variabel penelitian. c) menyusun kisi-kisi instrumen. d) melakukan uji coba instrumen. e) melakukan uji validitas dan reliabilitas instrumen.

\section{Hasil dan Pembahasan}

Hipotesis pertama pada penelitian ini adalah bahwa terdapat pengaruh antara kepemimpinan kepala sekolah terhadap 
produktivitas sekolah. Dilihat dari t hitung maka hipotesis pertama diterima, terlihat dari nilai $t$ hitung bila dibandingkan dengan nilai t tabel. Dimana t tabel yang dihasilkan adalah 1,994 sedangkan t hitung untuk variabel kepemimpinan kepala sekolah $\left(X_{1}\right)$ adalah sebesar 2,967. Dari hasil tersebut $t$ tabel lebih kecil dari t hitung, dengan begitu maka hipotesis pertama diterima. $\mathrm{H}_{0}$ ditolak dan $\mathrm{H}_{1}$ diterima, hal ini sejalan dengan penelitian yang dilakukan oleh Prasanti (2014).

Hipotesis kedua dalam penelitian ini akan mengkaitkan kinerja guru dengan produktivitas sekolah, dimana akan melihat adanya pengaruh antara kinerja guru sebagai variabel bebas terhadap produktivitas sekolah sebagai variabel terikat. Sebagaimana hipotesis pertama hipotesis kedua ini juga diterima. $\mathrm{H}_{0}$ ditolak dan $\mathrm{H}_{1}$ diterima. Hasil dari Uji Statistik $\mathrm{t}$ sebelumnya adalah $t$ hitung dari variabel kinerja guru $\left(X_{2}\right)$ diperoleh hasil sebesar 5,085, sedangkan $t$ tabel diperoleh 1,994, $t$ hitung lebih besar dari $t$ tabel. Dengan demikian maka terdapat pengaruh antara kinerja guru terhadap produktivitas sekolah. Penelitian ini searah dengan penelitian yang dilakukan oleh Rosidi (2011), yang mengungkapkan bahwa terdapat pengaruh antara variabel kinerja guru terhadap produktivitas sekolah.

Sebagaimana hasil uji hipotesis antara kedua variabel bebas yaitu kepemimpinan kepala sekolah dan juga kinerja sekolah secara terpisah dapat mempengaruhi variabel terikat yaitu produktivitas sekolah. maka penelitian ini juga akan melihat apakah secara parsial terdapat pengaruh antar variabel bebas yaitu kepemimpinan kepala sekolah dan kinerja guru dapat mempengaruhi variabel terikat yaitu produktivitas sekolah

Hasil penelitian ini menunjukkan bahwa hipotesis ketiga diterima. $\mathrm{H}_{0}$ ditolak dan $\mathrm{H}_{1}$ diterima. Hal ini melihat nilai $r$ square yang mencapai 40,7 persen yang termasuk kategori sedang dalam penggolongan klasifikasi nilai $R$ square, serta membandingkan antara nilai $f$ hitung dengan $f$ tabel. Dari hasil perhitungan Uji Statistik $F$ diperoleh nilai f hitung 28,164 sedangkan nilai $f$ tabel 3,11 . Nilai f hitung lebih besar dari $f$ tabel. Dengan demikian maka secara bersama-sama antara variabel kepemimpinan kepala sekolah, kinerja guru terdapat pengaruh terhadap produktivitas sekolah.

Meskipun penelitian ini membuktikan bahwa kepemimpinan kepala sekolah dan kinerja guru berpengaruh positif tetapi masih dalam kategori penggolongan sedang terhadap produktivitas kerja, artinya meskipun kepemimpinan kepala sekolah dan kinerja guru berpengaruh positif dan signifikan terhadap produktivitas
sekolah. 


\section{Kesimpulan dan Saran}

- Terdapat pengaruh positif $\left(B_{x 1}=0,082\right)$ antara kepemimpinan kepala sekolah dengan produktivitas sekolah. Hal ini mendukung hipotesis pertama yang telah peneliti susun

- Terdapat pengaruh positif $\left(B_{x 2}=0,421\right)$ antara kinerja guru dengan produktivitas sekolah. Hal ini mendukung hipotesis kedua yang telah disusun sebelumnya.

- Secara bersama-sama terdapat pengaruh positif $(F=20,164$; sig $=0,000)$ antara kepemimpinan kepala sekolah dan kinerja guru dengan produktivitas sekolah. Hal ini mendukung hipotesis ketiga yang telah disusun sebelumnya.

Hasil penelitian ini memperkuat kesimpulan dari penelitian terdahulu baik yang dilakukan oleh Prasanti (2014) maupun penelitian yang dilakukan oleh Rosidi (2011). Meski demikian tingkat adjusted $R$ square tergolong dalam klasifikasi sedang, yakni 40,7 persen, artinya masih terdapat variabel lain yang mungkin dapat mempengaruhi produktivitas sekolah.

Penelitian ini mendapatkan beberapa gambaran dan implikasi secara keilmuan, yakni:

- Produktivitas sekolah harus menjadi acuan dalam upaya peningkatan mutu sekolah, dalam hal ini produktivitas menjadi bagian yang integral kedudukannya dengan program sekolah lainnya, sehingga dalam perkembangan produktivitas itu sendiri mendapat dukungan dan aspirasi positif dari seluruh manajemen sekolah.

- Pembinaan manajemen sekolah yang baik dapat memacu peningkatan mutu sekolah, baik itu dari sisi pencapaian prestasi murid, peningkatan kinerja guru yang signifikan, kepemimpinan kepala sekolah yang dapat membuat manajemen sekolah bergairah dalam menunjukkan profesionalitas kerja, hubungan yang baik dengan komite sekolah, membina pola komunikasi yang baik dengan para stakeholder, dan beberapa hal lainnya yang dapat menjadikan sekolah bermutu baik dari sisi tenaga kerjanya maupun dari sisi prestasi yang dicapai oleh sekolah tersebut.

\section{Daftar Pustaka}

Aan Komariah, Engkoswara. 2010. Administrasi Pendidikan, Bandung: Alfabeta.

Bahri, Syamsul (2011). Faktor Yang Mempengaruhi Kinerja Guru SD Di Dataran Tinggi Moncong Kabupaten Gowa Provinsi Sulawesi Selatan. Jurnal MEDTEK ISSN:19071728 Vol. 3 No. 2 Oktober 2011. http://elektro.unm.ac.id/jurnal/Jurnal_MEDTEK_Vol.3_No.2 
Oktober_2011_pdf/PAk\%20 Ancu.pdf . 23/04/16 (diakses 01 Mei 2016)

E. Mulyasa, (2011), Menjadi Kepala Sekolah Profesional, Bandung : PT Remaja Rosdakarya.

Peraturan Pemerintah RI, 2005, Standar Nasional Pendidikan, Jakarta : CV Eko Jaya.

Prasanti, Anita. 2014. Pengaruh Kepemimpinan Kepala Sekolah, Kompetensi Guru, dan lingkungan kerja terhadap Produktivitas Sekolah.Universitas Guna Darma. no.2/Vol 2/September 2014 (diakses 01 Mei 2016)

Rosidi, Achmad. 2011. Pengaruh Gaya Kepemimpinan Kepala Sekolah Dan Kinerja Guru Terhadap Produktivitas Sekolah SMK Teknologi Dan Informasi Swasta di Wilayah Jakarta Selatan. Tesis. Program Pascasarjana Universitas Muhammadiyah Prof.DR.HAMKA Jakarta: Sekolah Pascasarjana http//lib.uhamka.ac.id/abstrak2.jsp?id=53170\&lokasi=lokal (diakses 01 Mei 2016)

Supriadi, Dedi. 2004. Membangun bangsa melalui pendidikan. Remaja Rosdakarya

Wahjosumijo, (2002), Kepemimpinan Kepala Sekolah, Jakarta: PT Raja Grafindo Persada

Wibowo, (2007), Manajemen Kinerja, Jakarta: PT Raja Grapindo Persada. 
